\title{
Agency Costs, Corporate Governance and Ownership Concentration: The Case of Agro-industrial Companies in Indonesia
}

\author{
Hastori $^{1}$, Hermanto Siregar ${ }^{1,2}$, Roy Sembel ${ }^{1,3} \&$ Tb. N Ahmad Maulana ${ }^{1}$ \\ ${ }^{1}$ Graduate School of Management and Business, Bogor Agricultural University, Indonesia \\ ${ }^{2}$ Department of Economics, Bogor Agricultural University, Indonesia; Department of Agricultural and Resource \\ Economics, Kasetsart University, Thailand \\ ${ }^{3}$ IPMI International Business School, Indonesia \\ Correspondence: Hastori, Graduate School of Management and Business, Bogor Agricultural University, Jl. \\ Padjajaran, Bogor, Indonesia. Tel: 62-81-181-6171. E-mail: hasunk@gmail.com
}

$\begin{array}{lr}\text { Received: March 16, } 2015 & \text { Accepted: April 2, } 2015 \quad \text { Online Published: June 5, } 2015 \\ \text { doi:10.5539/ass.v11n18p311 } & \text { URL: http://dx.doi.org/10.5539/ass.v11n18p311 }\end{array}$

\begin{abstract}
This study aims to investigate determinants of agency costs on agro-industrial firms that are listed in the Indonesian Stock Exchange (IDX). Modeling of agency costs is analyzed by performing regression analysis of panel data. This study employs secondary data of 54 companies from year 2010 to 2013 . The results show that agency costs are affected by the effectiveness of good governance mechanism, especially the function of board of directors (BOD) and board of commissioners (BOC) in conducting their duties, dividend payout and leverage. Whereas, independent commissioners and auditor committee are not significant factors in mitigating agency costs. Ownership concentration affects agency costs in vary. The results can help management, investors and other decision makers to implement better governance practices in agro-industrial firms in Indonesia.
\end{abstract}

Keywords: agency cost, ownership concentration, good governance, dividend payout

\section{Introduction}

Agency cost is a type of cost that arises from an agent as hired by a principal. In the context of business relationship, an agent (management) acts on behalf of a principal (shareholders) to run a business. Agency costs also refer to expenses and other costs associated with agency problems. Since an agent and a principal have different own personal interests, the business relationship may generate agency problems. If managers' objectives are not aligned with the owners' goals, agency problems will arise. Managers prefer to provide excessive perks and make self-interest decisions rather than exert to enhance shareholder wealth (Ang et al., 2000). With the implementation of good corporate governance, agency costs can be controlled.

Corporate governance is generally defined as the relationship between a firm's owners, managers, board of directors (BOD), and other stakeholders. This relationship is designed in the form of a contract to regulate all stakeholders' behavior to reach firm objectives. Recently, corporate governance covers not only beyond the scope of the formal contract, but also the way to pursue the common goals and to reward all parties involved (Gul \& Tsui, 2005).

Good corporate governance became a substantial issue when the Asian economic crisis happened in the late 1997. Indonesia, as one of the countries that most affected by the crisis, has been forced to seriously consider this issue at the national agenda for economic policies. Government Indonesia has introduced a "Code for Good Corporate Governance (GCG)", followed by establishing The National Committee on Corporate Governance 2000 for enhancing transparency, accountability, responsibility, and fairness. This Committee aimed to advocate GCG practices applied in Indonesian companies. Governance system can serve as rules of the game for every party to obey. Since each party in a company has own interests that may differ from each other, the governance system provides control to ensure that the business practices pursue the organization's objectives (Lukviarman).

After more than ten years implementation, however, the effectiveness of corporate governance is still questionable. According to Asian Corporate Governance Association (ACGA) survey in 2012, Indonesia market category score was only 37, or at bottom quartile, below other south-east Asia countries, such as the Philippines (41), Malaysia (53) and Thailand (58) (ACGA, 2012). 
Key mechanism of the corporate governance framework depends on the active function of boards of directors (BOD) and board of commissioners (BOC). BOC supervises and advises BOD in running business. Likewise, independence of supervisory and internal audit activities also took apart in the effectiveness of their monitoring function in providing checks and balances on a firm's operation.

Agency costs is also influenced by owner's concentration. Owner concentration refers to the portion of share hold by large-block shareholder (majority). A higher portion of owner concentration encourages a stronger power of shareholder in monitoring managers to run business. Large-block shareholders have incentives to proactively protect their investment. Their significant portion of shares may higher motivate the owner to monitor and discipline managers' behavior and to avoid inappropriate discretion of the managers (Patricks, 2002). The higher the ownership owned the more incentives for large block shareholders in protecting their money and consequently controlling management (La Porta et al., 2000; Pedersen \& Thomsen, 2003).

Indonesia, as a developing country, has a relatively small, undeveloped and illiquid capital market. This condition generates lack of discipline and control of management through the market for corporate control. Patrick (2002), argued that Indonesia Stock Exchange is not strong, ineffective self-regulating institution and lack of government oversight. In the context of weak control mechanisms that are prevalent in developed economies, majority as a reflection of owner concentration can serve as an alternative internal governance mechanism in mitigating agency problems (Shleifer \& Vishny, 1997; Burkart \& Panunzi, 2001).

This study aims to investigate the effects of governance mechanisms and ownership concentration in minimizing the agency costs. We use sample of companies that are listed in the "Indonesia Stock Exchange" from 2010 until 2013. This study investigates factors that affect agency costs. This study also wants to answer whether agency theory works well in Indonesian business terms, especially in agro-industry sector. The study participates in finding the solution that can mitigate the agency costs.

\section{Literature Review}

There are various forms of agency costs. Generally, agency cost refers to cost associated with an agency problems. For examples, a behavior of managers that focus on social status, use exclusive facilities (luxury buildings and executive cars), perform non-optimal investment, mismanage companies and take corporate fraud. Consequently, the existence of agency costs has lead to weaken a firm's competitiveness in global markets.

Agency costs may come from the condition when a majority (controlling shareholder) threats a minority unfairly by reducing minority welfare. There are many transactions between companies at prices that are advantageous only to the controlling shareholders without considering minority's interests. Those unfair transactions are usually happened in conglomeration. One firm purchases and sells assets, goods or services to another firm, but actually those firms are in the same owners (Firth et al., 2008).

\subsection{Ownership Concentration}

A study by La Porta et al. (1999) revealed that about sixty-four percent of large firms in the twenty-seven richest countries have controlling shareholders and control is often concentrated within a family. Furthermore, several studies in emerging and developing countries found the dominance of highly concentrated ownership among corporations. Therefore, ownership concentration becomes more important issue in terms of corporate governance.

There is a closely relationship between agency problems of firms in East Asia with their concentrated ownership (Fan and Wong, 2001). Large block shareholders with their high concentrated ownership help themselves to protect and get back their investment (Shleifer \& Vishny, 1997; Kang \& Sorensen, 1999). There is also evidence that large block shareholder can control agency costs more effectively than small block ones do (Ang et al., 2000; Singh \& Davidson, 2003).

\subsection{Board Size}

Good corporate governance reduces agency problems. The effectiveness of this governance depends on the role of all parties in a company. Under Indonesian Company Law, there are two tiers of boards, boards of directors and boards of commissioners. The position of the two boards is clearly separated. A Board of directors works to manage company's operation, while a board of commissioners works to perform advisory and to control management of a firm. There is evidence that large board is closely related to high performance of a firm due to its power and effectiveness (Pearce \& Zahra, 1991; Singh \& Davidson, 2003). However, Gul et al. (2012) found that small board is correlated to low agency costs. 


\subsection{Independent Commissioners}

Companies in Indonesia have also adopted an independent commissioner who has no affiliation with controlling shareholders and is elected by non-controlling shareholders. The Indonesia Stock Exchange regulate that the number of independent supervisory board members should be proportionally based on shares held by non-controlling shareholders. At least $30 \%$ of a company's supervisory board members should be independent.

The independence of commissioners can be used as a monitory mechanism. Many studies show how agency costs can be limited and controlled by the important function of the independent commissioners in conducting their tasks (Klein, 2006; Chtourou et al., 2001; Xie et al., 2003).

\subsection{Audit Committee}

Audit committees support the task of board of commissioners in enhancing management performance. Audit committees' duty is closely related to reviewing firm's annual report and revitalizing internal control process. So the firm will operate in frame of laws and regulations. Audit committee assists commissioners to actively take apart in developing strategic policies. The audit committee acts as an intermediary between the firm's managers and the external auditors when there are disputes over accounting matters. Audit committee also plays important governance role in Asia companies. The effective role of an audit committee will reduce agency problem, especially in acceptability of financial reporting and system of internal control (Fan \& Wong, 2001).

\subsection{Dividend Payout}

The dividend payout can reduce agency problems. By increasing dividend payout, the amount of free cash flow will be lower. Dividend policy can also show that controlling shareholders notice minority and do not intend to use free cash flow for themselves. This is called rent extraction hypothesis (Gugler \& Yurtoglu, 2002). Dividend can be the main role to limit the expropriation towards minority. By paying dividend shows that minority's right is fulfilled (Faccio et al., 2001).

\subsection{Leverage}

Debts can be used to lower agency costs, since they can reduce free cash flows. The existence of debt makes managers to use fewer perquisites and become more efficient, in order to avoid the probability of bankruptcy and the loss of control. An empirical study in the US shows how effectiveness of debts role in controlling managers (Ang et al., 2000). Differ from those in the US, debt markets in China is heavily influenced by the state that has various objectives (Firth et al., 2008).

Debts let public investors as minority be aware that majority will use available cash to pay debt first. In order to guarantee their money back, creditor will take over a part of shareholders' task in monitoring management (Faccio et al., 2001).

\subsection{Company Size}

Ang et al. (2000) and Singh \& Davidson (2003) suggest that the larger companies the more efficient they operate. In another words, larger companies are likely to have lower agency costs. The fact that larger firms may have some advantages compared to smaller ones makes it necessary to observe the impact of a firm's size.

Further, it is believed that larger firms are more likely to gain support in the form of critical resources from other stakeholders. Generally, larger firms are easier to access resources and overcome financial problems than of small ones, even in time of financial distress (Lukviarman, 2008).

\section{Conceptual Framework}

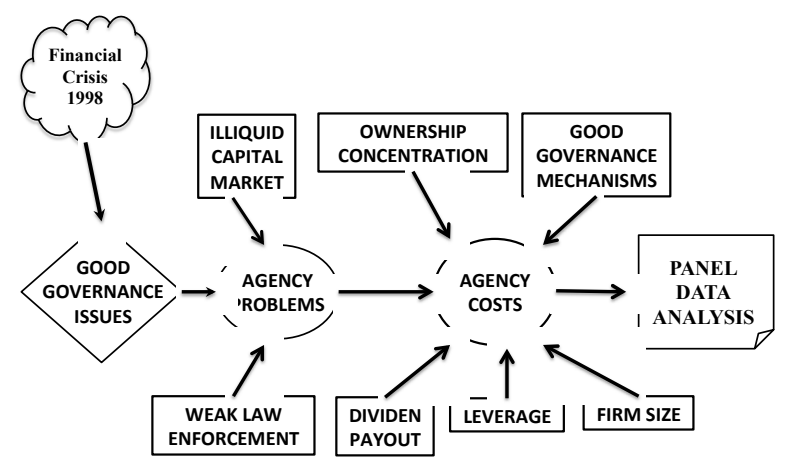

Figure 1. Conceptual framework of agency costs 
Figure 1 describes conceptual framework of agency costs.

\subsection{Hypothesis Development}

As discussed above, there is closely relationship between ownership concentration and agency costs. Claessens \& Djankov (1999) found that the more concentrated the ownership, the higher the firm's profitability and the lower agency costs. Some evidence also shows that concentrated ownership is negatively related to agency costs (Firth et al., 2008; Gul et al., 2012; Li et al., 2007). Hence, we propose first hypothesis

$\mathrm{H}_{1}$ - Agency costs of a firm will decrease if ownership concentration increases.

The effectiveness of good governance implementation depends on the function of board members in doing the right things. There are two tiers of boards that are clearly separated. Larger board tends to create high performance of a firm because of its power and effectiveness (Pearce \& Zahra, 2001; Singh \& Davidson 2003). Therefore, we propose two hypotheses:

$\mathrm{H}_{2}$ - Agency costs of a firm will decrease if the number of board of directors increases.

$\mathrm{H}_{3}$ - Agency costs of a firm will decrease if the number of board of commissioners increases.

The existence of independent commissioners is necessary to empower capability of board commissioners in supervising executives. There is positive relationship between the number of independent boards and profitability ratio of a firm (Krivogorsky, 2006). Independent commissioners are also assigned to primarily protect minorities' interests from controlling shareholders' expropriation (Lukviarman, 2008). Hence, independence commissioners can be used to mitigate conflicts between majority and minority. We propose hypothesis

$\mathrm{H}_{4}$ - Agency costs of a firm will decrease when the portion of independent commissioners increases.

Audit committee helps board of commissioners in overseeing financial reports in order to improve the quality and transparency of the financial matters. Audit committee should be independent and free from boards' influence. Kusnadi (2003), Ghosh et al. (2010) and Siregar \& Utama (2008) report that the number of audit committee significantly repress agency costs. Therefore, we propose the fifth hypothesis

$\mathrm{H}_{5}$ - Agency costs will become lower when companies have higher proportion of audit committee.

As discussed above that dividend payout and debt can be used to reduce agency cost because those variables can reduce the amount of free cash flows. Since there is no abundant cash in hand, managers may not take inappropriate discretion. By paying dividend, it also indicates that minorities has been filed their rights. Meanwhile, debts also can mitigate agency costs because of the shifting management monitoring from shareholders to creditors (Faccio et al., 2001). From this argument point of view, we propose two other hypotheses:

$\mathrm{H}_{6}$ - Agency costs decreases with increasing dividend payout.

$\mathrm{H}_{7}$ - Agency costs decreases with increasing leverage.

Finally, firms' size is closely related to their economic scale. Larger size of a firm represents its maturity and operation efficiency. Therefore, we propose other two hypotheses

$\mathrm{H}_{8}$ - Agency costs decreases with increasing sales.

$\mathrm{H}_{9}$ - Agency costs decreases with increasing assets.

\section{Data and Operationalization of Variables}

To examine whether governance mechanisms and ownership concentration work to reduce the agency costs of Agro-industrial firms in Indonesia, we use sample of all agro-industrial firms listed in Indonesia Stock Exchange. There are 60 firms and we drop six firms since they have no all variables. So, the sample used in the study consists of 54 firms and for which data is available on all variables. The time period of the study starts from 2010 until 2013. The data has been collected from Indonesia Commodity Market Directory (ICMD). All Annual Reports from companies have been officially audited and used as financial variables.

Fixed effect multivariate regression analysis and Generalized Least Square is used in order to examine all variables that determine agency costs.

\subsection{Dependent Variable}

Agency costs is used as a dependent variable. A proxy measure for agency costs is the sum of total operating, general and administration expenses (OGA) divided by total sales. Ang et al. (2000) and Singh \& Davidson 
(2003) use this proxy in their studies. OGA are expenses associated with sales activities, firm's operations and production. OGA also includes payment of wages of the boards and managerial discretion.

\subsection{Independent Variables}

There are nine variables that affect agency costs. Previous studies mostly consider only variables that represent ownership concentration, governance mechanisms and capital structure of a company. We add dividend payout variable as our novelty. The nine variables are as follows:

4.2.1 Ownership Concentration (OC): We measure OC as the percentage of total stock held by majority (Mir \& Nishat, 2004).

4.2.2 Board of Directors (BOD): We measure BOD by taking total board director members (Mir \& Nishat, 2004).

4.2.3 Board of Commissioners (BOC): We measure BOC by taking total board commissioner members (Mir \& Nishat, 2004).

4.2.4 Independent Commisioners (IC): We measure independent commissioners by taking the total independent commissioner members divided by total non-independent commissioner members (Mir \& Nishat, 2004).

4.2.5 Audit Committee (AUC): We measure AUC by taking the number audit committee members relative to total non-independent commissioner members (Mir \& Nishat, 2004).

4.2.6 Dividend Payout (DP): We measure DP by taking total dividend divided by total comprehensive earnings (Mutammimah \& Hartono, 2010).

4.2.7 Leverage (LEV): We measure LEV by taking total debts divided by total assets (Hadiprajitno, 2013)

4.2.8 Size (lnASSET): We measure ASET by calculating natural log of total assets.

4.2.9 Sales (InSALES): We measure SALES by calculating natural log of total sales.

\section{Multi Regression Analysis}

We use fixed effect multivariate regression analysis to examine the determinants of agency cost. The specifications of the multi regression equation are as follows:

$$
\begin{gathered}
\ln (\mathrm{AC})_{i t}=\alpha+\beta 1\left(\ln (\mathrm{OC})_{i t}\right)+\beta 2\left(\mathrm{BOD}_{i t}\right)+\beta 3\left(\mathrm{BOC}_{i t}\right)+\beta 4\left(\ln (\mathrm{IC})_{i t}\right)+\beta 5\left(\mathrm{AUC}_{i t}\right)+ \\
\left.\beta 6\left(\mathrm{DP}_{i t-l}\right)+\beta 7\left(\mathrm{LEV}_{i t}\right)+\beta 8\left(\ln \mathrm{ASSET}_{i t}\right)+\beta 9(\operatorname{lnSALES})_{i t}\right)+\delta_{i}+e_{\mathrm{it}} .
\end{gathered}
$$

Where:

ACit $=$ Agency costs for company $i$ at period $t$.

$\alpha=$ intercept of the equation.

$\delta \mathrm{i}=$ company-specific fixed effect

eit $=$ error term

\section{Analysis and Results}

\subsection{Descriptive Statistics}

Table 1 figure out descriptive statistics for nine variables that are examined. The descriptive statistics consist of mean, standard deviation, min and max values for each variable. There are 54 agro-industrial companies listed in the "Indonesia Stock Exchange" from 2010 until 2013. The financial data has been taken from Indonesia Capital Market Directory (ICMD).

From the Table 1, we can see that the mean value of AC variable is 0.1613 , with its standard deviation is 0.2104 . It indicates that the percentage of operating expenses to total sales is $16.13 \%$. The $\mathrm{OC}$ variable has a mean value of 0.5168 with its standard deviation of 0.2251 . It means that agro-industrial companies in Indonesia have very concentrated ownership, more than $50 \%$ of total shares owned by majority. The BOD variable has a mean value of 5.259 with its standard deviation of 2.011. This means that the average number of board of director members is more than 5 persons. The BOC variable has a mean value of 4.4769 with its standard deviation of 1.904 . This means that the average number of board of commissioner members is almost 5 persons. The BIN variable has a mean value of 0.8411 . It means that the percentage of independent commissioners to non-independent commissioners is $84.11 \%$. The mean of AUC variable is 0.3943 . It indicates that the percentage of committee audit members to non-independent commissioners is $39.43 \%$. The average value of DP variable and LEV 
variable are 0.2161 and 0.6296 respectively. It shows that firms gave high enough dividend payout to stockholders. Finally, the level of leverage is also very high more than $62 \%$ of total assets.

Table 1. Four years summary of descriptive statistics

\begin{tabular}{ccccccc}
\hline Variables & Symbol & Obs. & Mean & Std. Dev. & Min. & Max. \\
\hline Agency costs & AC & 216 & 0.162916 & 0.210403 & 0.007544 & 2.558682 \\
Ownership Concentration & OC & 216 & 0.516774 & 0.225092 & 0.1308 & 0.9914 \\
Boards of Directors & BOD & 216 & 5.259259 & 2.010995 & 2 & 11 \\
Board of Commissioners & BOC & 216 & 4.476852 & 1.904565 & 2 & 10 \\
Independent Commissioners & IC & 216 & 0.841105 & 0.753654 & 0 & 5 \\
Audit Committees & AUC & 216 & 0.394287 & 0.31102 & 0 & 1.5 \\
Dividend Payout & DP & 216 & 0.216072 & 0.342392 & 0 & 1.601365 \\
Leverage & LEV & 216 & 0.629593 & 0.478366 & 0.3955 & 3.210003 \\
Assets & ASSET & 216 & 14.57749 & 1.555458 & 11.37682 & 18.17777 \\
Sales & SALES & 216 & 14.53657 & 1.654436 & 9.381685 & 18.13334 \\
\hline
\end{tabular}

Notes: Obs. = Obesevation; Std.Dev. = Standard Deviation; Min. = Minimum; Max.= Maximum

\subsection{Correlation Matrix}

To examine the existence of multicolinearity among variables, we use Pearson's co-efficient of correlation. The problem of multicolinearity will exist, if there is a serious correlation. Maximum standard for multicolinearity is 0.80 . Table 2 figures out correlations among variables. Since there is no value of correlation matrix higher than 0.8 , it means that the data is free from serious multicolinearity problems among variables.

Table 2. Correlation matrix

\begin{tabular}{|c|c|c|c|c|c|c|c|c|c|}
\hline & $\mathrm{AC}$ & $\mathrm{OC}$ & BOD & $\mathrm{BOC}$ & IC & AUC & DP & LEV & ASSET \\
\hline $\mathrm{AC}$ & 1.0000 & & & & & & & & \\
\hline $\mathrm{OC}$ & -0.0300 & 1.0000 & & & & & & & \\
\hline BOD & -0.1306 & 0.2077 & 1.0000 & & & & & & \\
\hline $\mathrm{BOC}$ & -0.1264 & -0.0111 & 0.0336 & 1.0000 & & & & & \\
\hline IC & -0.0448 & -0.1302 & 0.0116 & 0.0364 & 1.0000 & & & & \\
\hline AUC & -0.0183 & 0.1415 & -0.0050 & -0.0318 & 0.0666 & 1.0000 & & & \\
\hline DP & -0.1481 & -0.0771 & -0.1056 & -0.0065 & 0.1672 & -0.0409 & 1.0000 & & \\
\hline LEV & -0.1500 & 0.2804 & 0.6075 & 0.1847 & -0.0759 & -0.0085 & -0.3218 & 1.0000 & \\
\hline ASSET & -0.3126 & 0.3480 & 0.6322 & 0.1761 & 0.0168 & 0.0002 & -0.2228 & 0.3055 & 1.0000 \\
\hline
\end{tabular}

\subsection{Regression Results and Discussion}

The results of fixed effect multivariate regression analysis are presented in Table 3.

The regression equation model is:

$$
\begin{gathered}
\ln (\mathrm{AC})_{i t}=1.531299+0.197004 \ln (\mathrm{OC})_{i t}-0.034661(\mathrm{BOD})_{i t}-0.031322(\mathrm{BOC})_{i t}+ \\
0.050837 \ln (\mathrm{IB})_{i t}+0.0078985(\mathrm{AUC})_{i t}-0.068749(\mathrm{DP})_{i t-1}+0.363713(\mathrm{LEV})_{i t}+ \\
0.001292 \ln (\mathrm{ASSET})_{i t}+\delta_{i}+e_{i t}
\end{gathered}
$$

Hence,

$$
\begin{gathered}
\mathrm{AC}_{\mathrm{it}}=\operatorname{Exp}\left[1.531299+0.197004 \ln (\mathrm{OC})_{i t}-0.034661(\mathrm{BOD})_{i t}-0.031322(\mathrm{BOC})_{i t}+\right. \\
0.050837 \ln (\mathrm{IB})_{i t}+0.0078985(\mathrm{AUC})_{i t}-0.068749(\mathrm{DP})_{i t-l}+0.363713(\mathrm{LEV})_{i t}+ \\
\left.0.001292 \ln (\mathrm{ASSET})_{i t}+\delta_{i}+e_{\mathrm{it}}\right]
\end{gathered}
$$

By having R-square $99.04 \%$, the above model explains $99.04 \%$ of the total variation of the data. Hence, the model meets a goodness of fit.

As shown in Table 3, we also employ regression analysis for big agro-industrial firms, small agro-industrial firms, domestic agro-industrial firms, and foreign agro-industrial firms separately. These analyses will be used to support argument in the certain condition. 
The Ownership Concentration (OC) variable has not influence to agency cost significantly. If we take further investigation, this result is in vary. For example for small agro-industrial firms, the ownership concentration has positive significant correlation with agency cost. However, for foreign agro-industrial firms, the ownership concentration and agency cost have negative significant correlation. The fact that ownership concentration of small agro-industrial firms is much higher than of foreign agro-industrial firms can explain the correlation between agency cost and ownership concentration. The regression pattern of agency cost and ownership concentration is possibly quadratic. And for the ownership concentration of foreign agro-industrial firms has not achieved peak point, so higher concentration will lower agency cost. However, because the ownership concentration of small agro-industrial firms has exceeded the peak point, so the higher the concentration the higher the agency cost.

Our result also shows that the size of both board directors and board of commissioners each has significant negative association with agency cost. Our result supports the hypothesis. Large size of board plays a substantial role in lowering unnecessary agency costs.

Table 3. Research result

\begin{tabular}{|c|c|c|c|c|c|c|}
\hline \multirow{2}{*}{ Variables } & \multirow{2}{*}{ Symbol } & \multicolumn{5}{|c|}{ Agency Costs } \\
\hline & & Agro-Industry & Big Agro & Small Agro & Domestic & Foreign \\
\hline Intercept & $\mathrm{C}$ & $1.531299 * *)$ & $0.299819 * * *)$ & 0.009379 & $\left.5.713686^{* * *}\right)$ & $0.629638 * * *)$ \\
\hline $\begin{array}{c}\text { Ownerhip } \\
\text { Concentration }\end{array}$ & $\mathrm{OC}$ & 0.197004 & --- & $5.050803 * * *)$ & 0.340012 & $-0.056746 * *)$ \\
\hline Board of Directors & BOD & $-0.034661 * * *)$ & $\left.-0.003338^{*}\right)$ & $\left.0.104889^{*}\right)$ & $-0.053998 * *)$ & $\left.-0.007751^{* * *}\right)$ \\
\hline $\begin{array}{c}\text { Boards of } \\
\text { Commissioners }\end{array}$ & $\mathrm{BOC}$ & $-0.031322 *)$ & $-0.004052 *)$ & -0.024657 & $-0.063470 * *)$ & --- \\
\hline $\begin{array}{c}\text { Independent } \\
\text { Commissioners }\end{array}$ & IC & $0.050837 * *)$ & --- & --- & $-0.644480 * * *)$ & -0.004276 \\
\hline Audit Committees & AUC & $0.0078985 *)$ & $0.015022 *)$ & $0.232362 * *)$ & $-0.256395 * * *)$ & $\left.0.020252^{* * *}\right)$ \\
\hline Dividend Payout & DP & $-0.068749 * * *)$ & $-0.013436 * *)$ & -0.045587 & 0.037892 & -0.008149 \\
\hline Leverage & LEV & $\left.0.363713^{* * *}\right)$ & 0.009499 & --- & --- & $0.056405 * * *)$ \\
\hline LnASSET & $\ln \mathrm{ASSET}$ & 0.001292 & $0.070818 * * *)$ & $-0.204632 *)$ & --- & --- \\
\hline LnSALES & lnSALES & --- & $-0.079874 * * *)$ & --- & --- & $\left.-0.017856^{* * *}\right)$ \\
\hline $\mathrm{R}$-square & & 0.990408 & 0.980685 & 0.824369 & 0.532686 & 0.993522 \\
\hline Adj-R-square & & 0.986609 & 0.972653 & 0.740213 & 0.507873 & 0.990533 \\
\hline $\begin{array}{c}\text { Durbin-Watson } \\
\text { Stat }\end{array}$ & & 2.267363 & 1.985018 & 1.463373 & 0.841229 & 2.177551 \\
\hline F-Statistic & & 260.6753 & 122.0966 & 9.795675 & 21.46795 & 332.3236 \\
\hline Prob (F-stat) & & 0.00000 & 0.0000 & 0.0000 & 0.0000 & 0.0000 \\
\hline Total Observation & & 216 & 144 & 72 & 120 & 96 \\
\hline Model & & FEM & FEM & FEM & Pooled EGLS & FEM \\
\hline Panel Option & & $\begin{array}{l}\text { Pooled EGLS } \\
\text { (Cross Sec } \\
\text { Weight) }\end{array}$ & $\begin{array}{c}\text { Pooled EGLS } \\
\text { (Cross Sec } \\
\text { Weight) }\end{array}$ & $\begin{array}{c}\text { Pooled Least } \\
\text { Squares }\end{array}$ & $\begin{array}{l}\text { Cross Sec } \\
\text { Weight }\end{array}$ & $\begin{array}{c}\text { Pooled EGLS } \\
\text { (Cross Sec } \\
\text { Weight) }\end{array}$ \\
\hline
\end{tabular}

Sources: treated data

*) significant at $10 \%$ level

**) significant at $5 \%$ level $\quad * * *$ ) significant at $1 \%$ level

In relation to independent commissioners, result shows that the correlation between independent commissioners and agency cost is positive significant. It means that the higher portion of the independent commissioners to dependent commissioners the higher agency costs. This condition figures out that independent commissioners do not work effectively as the representative of minority. However, for the domestic firms, results show differently. The relation between agency cost and independent commissioners for domestic firms is significantly negative. This condition supports the hypothesis. The higher the portion of independent commissioners will lower agency costs.

Regarding to audit committee, result shows that audit committee is positively related to agency costs. The higher portion of audit committee members the higher agency cost. This result is contradictive with the hypothesis. We hypothesize that the presence of this committee in a firm will improve its corporate governance, which in turn will decrease agency costs. This condition indicates that the role of audit committee in helping boards to monitor the performance of managers is not effective. However, there is actually negative relation between audit committee and agency problem, especially for big agro-industrial firms. This negative relation is significant at level 1 percent. 
Dividend payout policy mitigates agency cost significantly. This condition works also for big agro-industrial firms. By increasing dividend payment agency costs will be lower, especially costs that arise from minority and majority problems. Dividend payout policy will also lower the cash flows, so that it limits management to take discretion or invest in negative projects.

Result shows that leverage variable has significantly positive relation with agency cost. This means that agency cost will be higher when firms have higher leverage. This condition also happens for foreign firms. This is because of the high level of debt structure of firms. As mentioned earlier, the leverage of firms in Indonesia is very high. So, by taking more debts will increase risks of bankruptcy. These risks also create other problems between managers and creditor.

Result shows that firm's size does not affect agency cost of the firms.

\section{Conclusion}

The result shows that agency costs are primarily affected by board of directors, by board of commissioners, by independent commissioners, by audit committees, by dividend payout and by leverage.

Larger size of board of directors and board of commissioners each reduces the level of agency cost. These results are consistent with hypothesis. The presence of these boards effectively affect in reducing agency cost incurred in agro-industrial firms.

Independent commissioners have positive association with agency cost. Likewise, audit committees have positive relationship with agency cost. These two findings are contrary to the research hypothesis. These mean that the presence of two bodies do not effectively reduce agency problems.

Dividend payout policy has negative significantly associated with agency costs. The higher the payment of dividend the lower agency costs incurred. This finding indicates that the dividend policy can be used to mitigate the agency problem between majority shareholders and minority shareholders. On the other hand, leverage has significantly positive relation with agency costs.

Ownership concentration affects agency problems in vary. Generally, it can be concluded that agency theory actually does work more effectively in terms of business in Indonesia. Some variables of corporate governance practices affect in reducing agency cost. Even though our study is categorized as an embryonic stage in analyzing agency costs, however firms' management, investors, government and other stakeholders should consider those variables in order to control agency problems.

\section{References}

Ang, J. S., Cole, R. A., \& Lin, J. W. (2000). Agency Costs and Ownership Structure. J. of Finance, 55(1), 81-106. http://dx.doi.org/10.1111/0022-1082.00201

Asian Corporate Governance Association [ACGA]. (2000). Building Stronger Boards and Companies in Asia: a Concise Report on Corporate Governance Policies and Practices. Survey Report. Hongkong (CH). The Asian Corporate Governance Association Limited.

Burkart, M., \& Panunzi, F. (2001). Agency Conflicts, Ownership Concentration, and Legal Shareholder Protection. J. of Financial Intermediation, 15.

Chtourou, S. M., Bedard, J., \& Corteau, L. (2001). Corporate Governance and Earning Management. Working Paper.

Claessens, S., \& Djankov, S. (1999). Ownership Concentration and Corporate Performance in the Czech Republic. J. of Comparative Economic, 27, 498-513. http://dx.doi.org/10.1006/jcec.1999.1598

Faccio, M., Lang, L. H. P., \& Young, L. (2001). Dividends and expropriation. American Economic Review, 91, 54-78. http://dx.doi.org/10.1257/aer.91.1.54

Fan, J. P. H., \& Wong, T. J. (2001). Do External Auditor Perform a Corporate Governance. Role in Emerging Markets, Evidence from East Asia. Working Paper No. 400.

Firth, M., Fung, P. M. Y., \& Rui, O. M. (2008). Ownership, Governance Mechanisms, and Agency Costs in China's Listed Firms. J. of Asset Management, 9(2), 90-101. http://dx.doi.org/10.1057/jam.2008.13

Florackis, C. (2008). Agency Costs and Corporate Governance Mechanisms: Evidence for UK Firms. International J. of Managerial Finance, 4(1), 37-59. http://dx.doi.org/10.1108/17439130810837375

Ghosh, A., Marra, A., \& Moon, D. (2010). Corporate Boards, Audit Committees and Earnings Management: Pre-andPost-SOX Evidence. Blackwell Publishing Ltd. http://dx.doi.org/10.1111/j.1468-5957.2010.02218.x 
Gugler, K., \& Yurtoglu, B. B. (2002). Corporate Governance and Dividend Pay-Out Policy in Germany. European Economic Review, 47, 731-758. http://dx.doi.org/10.1016/S0014-2921(02)00291-X

Gul, F. A., \& Tsui, J. S. L. (2005). The Governance of East Asian Corporations. Palgrave MacMillan. N.Y.

Gul, S., Sajid, M., Razzaq, N., \& Afzal, F. (2012). Agency Cost, Corporate Governance and Ownership Structure (The case of Pakistan). International J. of Business and Social Science, 3(9), 268-277.

Hadiprajitno, P. B. (2013). Struktur Kepemilikan, Mekanisme Tata Kelola Perusahaan, dan Biaya Keagenan di Indonesia (Studi Empirik pada Perusahaan di Bursa Efek Indonesia. J Akuntansi dan Auditing, 9(2), 97-127.

Kang, D. L., \& Sorensen, A. B. (1999). Ownership Organization and Firm Performance. Annual Review of Sociology, 25, 121-144. http://dx.doi.org/10.1146/annurev.soc.25.1.121

Klein, A. (2006). Audit Committee, Board of Director Characteristics, and Earning Management. Working Paper No. 06-42. NYU.

Krivogorsky, V. (2006). Ownership, Board Structure, and Performance in Continental Europe. The International J. of Accounting, 41, 176-197. http://dx.doi.org/10.1016/j.intacc.2006.04.002

Kusnadi, Y. (2003). Corporate Cash Holdings and Corporate Governance Mechanism. Paper disajikan di Hong Kong University of Science dan di National University of Singapore. http://dx.doi.org/10.2139/ssrn.479401

La Porta, R., Lopez-de-Silanes, F., \& Shleifer, A. (1999). Corporate Ownership Around the World. J. of Finance, 54(2), 471-517. http://dx.doi.org/10.1111/0022-1082.00115

La Porta, R., Lopez-de-Silanes, F., Shleifer, A., \& Vishny, R. (2000). Investor Protection and Corporate Governance. J. of Financial Economics, 58(1-2), 3-27. http://dx.doi.org/10.1016/S0304-405X(00)00065-9

Li, H., Wang, Z., \& Deng, X. (2009). Ownership, independent directors, agency costs and financial distress: Evidence from Chinese Listed Companies. Corporate Governance, 8(5), 622-636. http://dx.doi.org/10. 1108/14720700810913287

Lukviarman, N. (2004). Ownership Structure and Firm Performance: The Case of Indonesia. Disertasi Tidak Dipublikasikan. Curtin University of Technology, Perth (AU).

Mir, S., \& Nishat, M. (2004). Corporate governance structure and firm performance in Pakistan- an empirical study. Presented at the 2nd Annual conference on Corporate Governance. Lahore University of Management Sciences.

Mutamimah, \& Hartono, S. (2010). Dividend, Debt, and Investment Policies as Corporate Governance Mechanisms. Investment Management and Financial Innovation, 7(2), 209-216.

Patrick, H. (2002). Corporate Governance and the Indonesian Financial System: a Comparative Perspective. APEC Study Center Columbia Business School. Discussion paper 16. July.

Pearce, J. A., \& Zahra, S. A. (1991). The relative power of CEOs and boards of directors: associations with corporate performance. Strategic Management J., 12, 135-153. http://dx.doi.org/10.1002/smj. 4250120205

Pederson, T., \& Thomsen, S. (2003). Ownership structure and value of largest european firms: the importance of owner identity. J. of Management \& Governance, 7(1), 27-55. http://dx.doi.org/10.1023/A:1022480016567

Shleifer, A., \& Vishny, R. W. (1997). A Survey of Corporate Governance. J. of Finance, 52(2), 737-783. http://dx.doi.org/10.1111/j.1540-6261.1997.tb04820.x

Singh, M., \& Davidson, W. N. (2003). Agency Cost, Ownership Structure and Corporate Governance Mechanisms. J. of Banking and Finance, 27,793-816. http://dx.doi.org/10.1016/S0378-4266(01)00260-6

Siregar, S. U., \& Utama, S. (2008). Type of Earnings Management and the Effect of Ownership Structure, Firm Size, and Corporate-Governance Practices. Evidence from Indonesia. The International J. of Accounting, 43, 1-217. http://dx.doi.org/10.1016/j.intacc.2008.01.001

Xie, B., Davidson, W. N. III, \& DaDalt, P. J. (2001). Earning Management and Corporate Governance: The Roles of the Board and the Audit Committee. Working Paper.

\section{Copyrights}

Copyright for this article is retained by the author(s), with first publication rights granted to the journal.

This is an open-access article distributed under the terms and conditions of the Creative Commons Attribution license (http://creativecommons.org/licenses/by/3.0/). 